\title{
Behavior of Reinforced Retaining Walls with Different Reinforcement Spacing during Vehicle Collisions
}

\author{
Kwangkuk Ahn and Hongsig Kang \\ Department of Civil Engineering, Chungbuk National University, Cheongju, Chungbuk 361-763, Republic of Korea \\ Correspondence should be addressed to Kwangkuk Ahn; akk@chungbuk.ac.kr
}

Received 21 April 2015; Revised 11 June 2015; Accepted 14 June 2015

Academic Editor: Robert Cerný

Copyright ( $) 2015$ K. Ahn and H. Kang. This is an open access article distributed under the Creative Commons Attribution License, which permits unrestricted use, distribution, and reproduction in any medium, provided the original work is properly cited.

\begin{abstract}
Accidents involving vehicles crashing into reinforced retaining walls are increasing because of the increased construction of reinforced retaining walls on roads. Unlike a normal retaining wall, a reinforced retaining wall is not one united body but is made up of blocks. Hence, a reinforced wall can break down when a vehicle crashes into it. The behavior of such a wall during vehicle collision depends upon the reinforcement material used for its construction, its design, and the method of the construction. In this study, the behavior of a reinforced retaining wall was analyzed while changing the reinforcement spacing using LS-DYNA, a general finite-element program. Eight tons of truck weight was used for the numerical analysis model. The behavior of a reinforced retaining wall under variable reinforcement spacing and positioning was analyzed. The results indicated that the reinforcement material was an important resistance factor against external collision load.
\end{abstract}

\section{Introduction}

Continuously increasing volumes of traffic have resulted in problems of traffic congestion. To solve this problem, a large number of underpasses, crossroads, and elevated roads have recently been constructed. Small and large reinforced retaining walls, which are both economical and beneficial in terms of construction efficiency, are being constructed along the sides of roads. As the construction of reinforced retaining walls along roads that cater to high traffic volume increases, vehicle collisions with these walls also increase.

A reinforced retaining wall is constructed by gradually increasing the tensile force applied to the soil on the backside of the wall. In this method, the wall is reinforced by using high-tensile-strength reinforcing materials such as geotextiles. The material type, construction interval, and length of the reinforcing material are considered important design factors when designing a reinforced retaining wall. However, a reinforced wall is built of blocks and is not one united body, so a vehicle colliding with it can potentially cause secondary damage owing to the collapse of the retaining wall and the settlement of backfill.

In order to investigate the characteristics of behavior and failure mechanisms of reinforced retaining walls, model tests and numerical analyses were carried out by changing the length and spacing of reinforcement, surcharge load, and backfill properties studied by Wong, Pinto, Leshchinsky, Ghionna, Yoo, Liu, Stuedlein, and Suliman [1-8]. The safety of construction structures according to vehicle collision was verified with vehicle crash tests and numerical collision analyses by Wu, Borovinšek, Chung, Itoh, Tay, and Kim [914]. However, the effect of vehicle collision on reinforced retaining walls was excluded. Additionally, the safety of reinforced retaining walls affected by vehicle collision for different vehicle velocities was recently studied by Ahn et al. [15]; however, the effect of design factors on reinforced retaining walls was not considered.

In this study, a collision analysis was conducted to identify the behavior of reinforced retaining walls with spacing of reinforcement when a vehicle crashed into the reinforced retaining wall. This analysis was conducted with threedimensional nonlinear dynamic time history analysis using LS-DYNA, a general finite-element analysis program, to identify the behavior of reinforced retaining walls during vehicle collision. An eight-ton single-unit Ford truck offered by the National Crash Analysis Center (NCAC) was used for the vehicle collision analysis. Behavior of reinforced retaining walls from vehicle collisions was analyzed by comparing 
TABLE 1: Relationship between design and collision velocities.

\begin{tabular}{lccc}
\hline Type & $\begin{array}{c}\text { The range of design } \\
\text { velocity in road } \\
(\mathrm{km} / \mathrm{h})\end{array}$ & $\begin{array}{c}\text { Used design } \\
\text { velocity }(\mathrm{km} / \mathrm{h})\end{array}$ & $\begin{array}{c}\text { Collision } \\
\text { velocity }(\mathrm{km} / \mathrm{h})\end{array}$ \\
\hline A & $60 \sim 120$ & 100 & 60 \\
B & 60 & 60 & 40 \\
C & $20 \sim 50$ & 50 & 35 \\
D & - & 100 & 80 \\
\hline
\end{tabular}

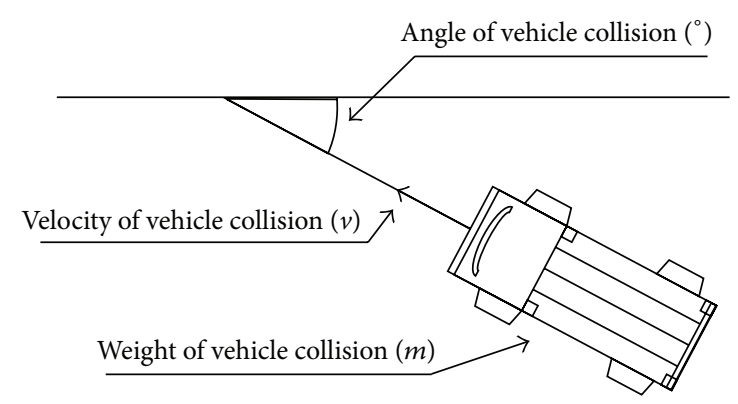

FIGURE 1: Condition of impact severity.

the displacement of the front side, horizontal and vertical, of the reinforced retaining wall's block at the point of collision from the ground surface to $1.0 \mathrm{H}$ which is the height of the reinforced retaining wall at intervals of $0.2 \mathrm{H}$.

\section{Conditions of Vehicle Collision}

The guidelines for vehicle collisions found in "guidelines for installation and administration of road safety facility" along with "business guide for vehicle crash test of safety barrier provided in Korea" were considered in this study [16, 17].

2.1. Calculation of Impact Severity. The impact severity was defined by the kinetic energy which is created when a vehicle crashes into a structure. Figure 1 shows the condition of vehicle collision and the impact severity is computed as follows:

$$
\text { IS }=\frac{1}{2} m\left(\frac{v}{3.6} \sin \theta\right),
$$

where IS is impact severity $(\mathrm{kg}), m$ is weight of vehicle collision (ton), $v$ is velocity of vehicle collision $(\mathrm{km} / \mathrm{h})$, and $\theta$ is angle of vehicle collision $\left(^{\circ}\right)[16,17]$.

2.2. The Velocity of Vehicle Collision. According to "guidelines for installation and administration of road safety facility in Korea" the vehicle collision velocity can be as high as $80 \%$ of the design velocity. Table 1 shows the relationship between the design and collision velocities on the road [17], for each type of vehicle. Therefore $80 \mathrm{~km} / \mathrm{h}$ of collision velocity was chosen to consider the conditions of the roads in Korea in this study.

2.3. Weight of Vehicle Collision. For small vehicles and large vehicles, the "guidelines for installation and administration of road safety facility" laid down rules governing the weights of
TABLE 2: Properties of truck model.

\begin{tabular}{lc}
\hline Type & Truck \\
\hline The number of elements & \\
Shell & 19,479 \\
Solid & 1,248 \\
Beam & 124 \\
Total & 20,727 \\
Weight (kg) & 8,035 \\
Yield stress (MPa) & 270 \\
Modulus of elasticity (MPa) & 205,000 \\
\hline
\end{tabular}

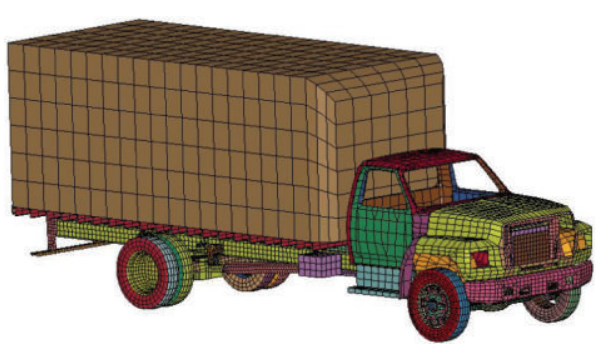

FIgURE 2: Three-dimensional model of Ford single-unit truck.

allowed vehicles in Korea. The weights of the vehicles ranged from 3.5 to 8.0 tons, and these were used as the design weights for the crashed vehicles $[16,17]$. Therefore the weight of the collided vehicle was chosen to be 8 tons and the eight-ton Ford single-unit truck, which is the finite-element model offered by the National Crash Analysis Center (NCAC), was used for the vehicle collision analysis in this study.

2.4. Angle of Vehicle Collision. The angle which is the included angle between the structure and the crashed vehicle is widely known to be $15^{\circ}$ for a straight road and $16^{\circ}$ for a curved road. "Guidelines for installation and administration of road safety facility" used $15^{\circ}$ for large vehicles and $20^{\circ}$ for small vehicles in Korea [17]. Therefore $15^{\circ}$ was used for the angle in this study.

\section{Numerical Analysis for Different Reinforcement Spacing}

3.1. Numerical Model of Vehicle. In this study, the numerical model used to model the vehicle is an eight-ton truck model (a Ford single-unit truck). It can be modeled using LSDYNA and is recommended by the NCAC. Figure 2 shows a three-dimensional model of the vehicle. The model consists of 19,479 shells, 124 beams, and 1,248 solid elements. The steel material used has a $270 \mathrm{MPa}$ yield stress and $205 \mathrm{GPa}$ modulus of elasticity, as shown in Table 2 [15].

3.2. Properties of the Reinforced Retaining Wall. The model of the reinforced retaining wall which was $20,000(W) \times$ $10,000(L) \times 5,200(H) \mathrm{mm}$ consisted of block, reinforcement, crushed stone, and backfill (Figure 3$)$. The block, $400(W)$ $\times 400(L) \times 200(H) \mathrm{mm}$, was modeled with solid elements and its material was Elastic_Tiltel in LS-DYNA as in Table 3. 
TABLE 3: Properties of reinforcement.

\begin{tabular}{lcccc}
\hline Type & Material of model (in LS-DYNA) & Unit weight $\left(\mathrm{kN} / \mathrm{m}^{3}\right)$ & Modulus of elasticity (MPa) & Poisson ratio \\
\hline Beam & Piecewise_linear_plasticity & 0.1 & 3,000 & 0.25 \\
\hline
\end{tabular}

TABle 4: Properties of reinforced retaining wall's block.

\begin{tabular}{|c|c|c|c|c|c|}
\hline Type & Size $(\mathrm{mm})$ & Material of model (in LS-DYNA) & Unit weight $\left(\mathrm{kN} / \mathrm{m}^{3}\right)$ & Modulus of elasticity (MPa) & Poisson ratio \\
\hline$\overline{\text { Solid }}$ & $400 \times 400 \times 200$ & Elastic_Title & 23.5 & 5000 & 0.3 \\
\hline
\end{tabular}

TABle 5: Properties of crushed stone and backfill.

\begin{tabular}{|c|c|c|c|c|c|}
\hline Type & $\begin{array}{l}\text { Material of model } \\
\text { (in LS-DYNA) }\end{array}$ & $\begin{array}{c}\text { Unit weight } \\
\left(\mathrm{kN} / \mathrm{m}^{3}\right)\end{array}$ & $\begin{array}{c}\text { Internal friction } \\
\text { angle }\left(^{\circ}\right)\end{array}$ & $\begin{array}{l}\text { Bulk modulus of } \\
\text { elasticity (MPa) }\end{array}$ & $\begin{array}{c}\text { Shear modulus } \\
(\mathrm{MPa})\end{array}$ \\
\hline $\begin{array}{l}\text { Crushed } \\
\text { stone }\end{array}$ & FHWA_Soil_Title & 19.0 & $45^{\circ}$ & 0.465 & 0.186 \\
\hline Backfill & FHWA_Soil_Title & 19.0 & $30^{\circ}$ & 0.35 & 0.14 \\
\hline
\end{tabular}

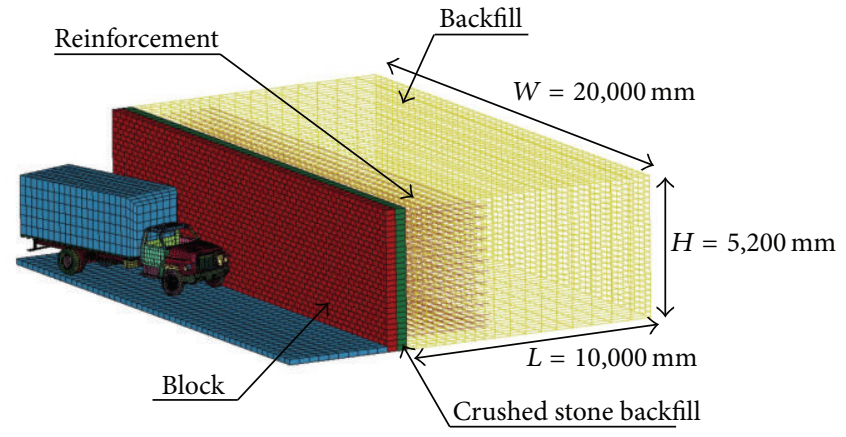

FIGURE 3: Collision analysis model of reinforced retaining wall.

Also the contact condition between the blocks is defined by the automatic_single_surface function in LS-DYNA. Reinforcement was modeled with beam elements and its material was Picewise_linear_plasicity in LS-DYNA as in Table 4. The coincident function in LS-DYNA was used for reinforcement to couple the block and backfill. Crushed stone and backfill of the reinforced retaining wall were modeled with solid elements and this material was FHWA_Soil_Title as seen in Table 5. Nodes of each element of crushed stone and backfill were merged to integrate movement. Vehicle collisions were simulated with each model, using a contact algorithm to model the wall behavior. Tables 3, 4, and 5 show details of each created model [15].

3.3. Spacing of Reinforcement. In general, in the design of reinforced retaining walls, reinforcement is installed and its spacing is denser from the top to the bottom in consideration of the earth pressure. However, as in Figure 4, the reinforcement was placed at equal-intervals of 200, 400, and $600 \mathrm{~mm}$ from the top of the reinforced retaining wall to determine the effect of varying intervals of reinforcement on vehicle collision and a collision analysis was conducted.

The observation point was measured from the ground surface to $1.0 \mathrm{H}$ at intervals of $0.2 \mathrm{H}$. The reinforcement was not placed at the top of the reinforced retaining wall because it could not perform the function of reinforcement.

\section{Results of Analysis}

4.1. Behavior of Reinforced Retaining Wall with Different Reinforcement Spacing. A collision analysis was conducted using LS-DYNA, a general finite-element analysis program, to identify the behavior of the reinforced retaining wall during vehicle collision. The contact condition between the reinforced retaining wall and the truck is defined by the contact_Automatic_surface_to_surface function in LSDYNA, and the result of the collision simulation is shown in Figure 5.

4.1.1. Displacement of Block with $200 \mathrm{~mm}$ Reinforcement Spacing. Table 6 shows the vertical and horizontal displacement with respect to the height $(H)$ of the reinforced retaining wall block for $200 \mathrm{~mm}$ reinforcement spacing and presents the separation ratio by contrasting the original block size with the maximum displacement of the block. Figure 6 shows the vertical and horizontal displacements of the front block, plotted at $0.2 H, 0.4 H, 0.6 H, 0.8 H$, and $H$ from the bottom of the reinforced retaining wall for $200 \mathrm{~mm}$ reinforcement spacing. In Figure 6(a), a positive value of horizontal displacement implies that the block moved toward the backfill of the reinforced retaining wall, and a negative value of horizontal displacement implies that the block moved toward the collided vehicle. In Figure 6(b), a positive value for vertical displacement indicates the bulging of the block and a negative value of vertical displacement indicates the subsidence of the block.

The final horizontal displacement at $0.2 \mathrm{H}$ (which was closest to the collision contact surface) was $2.6 \mathrm{~mm}$, and the final horizontal displacement at $H$ (furthest from the collision contact surface) was $5.9 \mathrm{~mm}$. Relatively smaller final horizontal displacements were observed in these two positions on the reinforced retaining wall, as compared to the other positions. The final horizontal displacement at $0.6 \mathrm{H}$ was found to be the largest, at $42.8 \mathrm{~mm}$. For horizontal displacement, 
TABLE 6: Block displacement for $200 \mathrm{~mm}$ reinforcement spacing.

\begin{tabular}{|c|c|c|c|c|c|c|}
\hline \multirow[b]{2}{*}{ Height } & \multicolumn{3}{|c|}{ Horizontal displacement (mm) } & \multicolumn{3}{|c|}{ Vertical displacement (mm) } \\
\hline & $\begin{array}{c}\text { Maximum } \\
\text { horizontal } \\
\text { displacement }\end{array}$ & $\begin{array}{c}\text { Separation ratio } \\
(\%)\end{array}$ & $\begin{array}{c}\text { Final horizontal } \\
\text { displacement }\end{array}$ & $\begin{array}{c}\text { Maximum } \\
\text { vertical } \\
\text { displacement }\end{array}$ & $\begin{array}{c}\text { Separation ratio } \\
(\%)\end{array}$ & $\begin{array}{l}\text { Final vertical } \\
\text { displacement }\end{array}$ \\
\hline $0.2 H$ & 20.5 & 5.1 & 2.6 & 22.2 & 11.1 & -11.5 \\
\hline $0.4 H$ & 26.6 & 6.7 & 26.6 & -42.2 & 21.1 & -42.2 \\
\hline $0.6 H$ & 42.8 & 10.7 & 42.8 & -48.6 & 24.3 & -48.6 \\
\hline $0.8 H$ & 33.2 & 8.3 & 30.8 & -57.9 & 29.0 & -57.9 \\
\hline$H$ & -41.3 & 10.3 & 5.9 & -68.1 & 34.0 & -68.1 \\
\hline
\end{tabular}

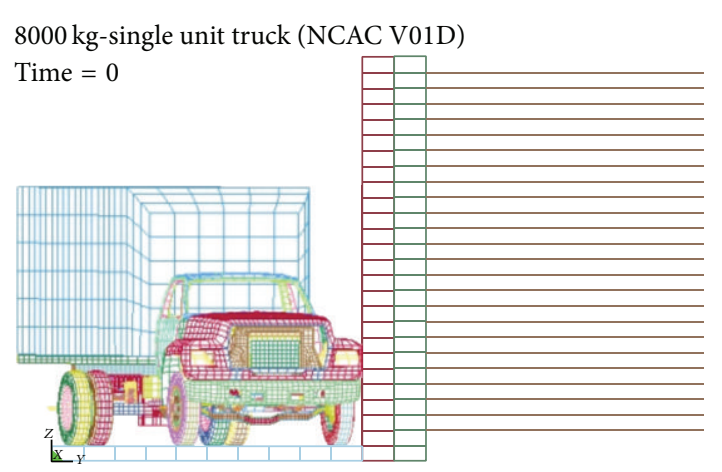

(a) $200 \mathrm{~mm}$ spacing

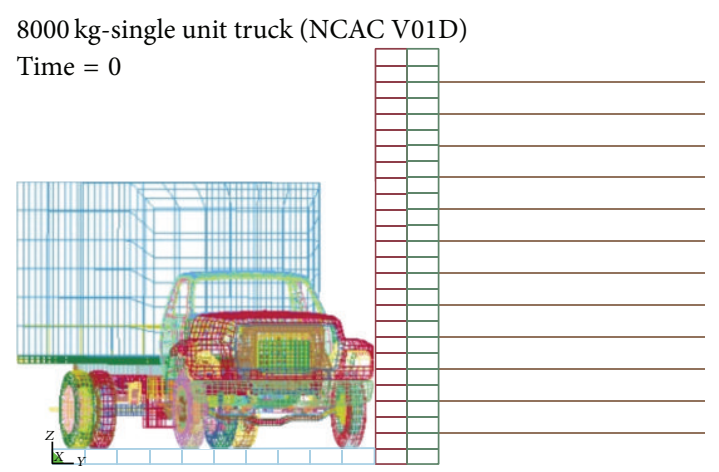

(b) $400 \mathrm{~mm}$ spacing

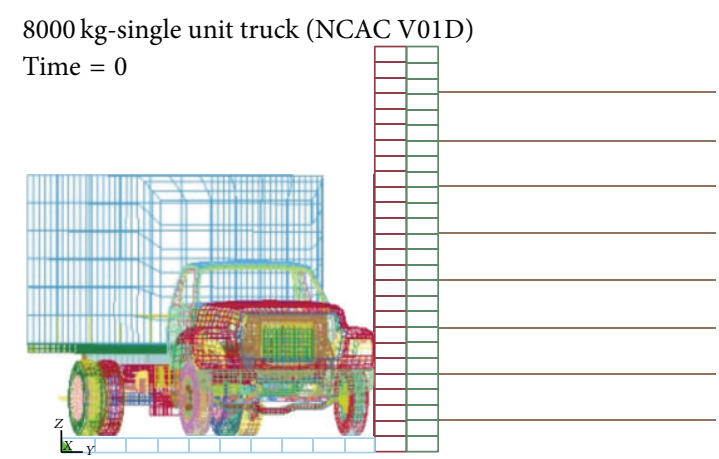

(c) $600 \mathrm{~mm}$ spacing

FIgURE 4: Analysis model for different reinforcement spacing.

the separation ratio, which contrasts the original block size with the maximum displacement of the block, ranged between 5.1 and $10.3 \%$. The final vertical displacement was found to be negative, and the displacement increased with height. The final vertical displacement was maximum at $H$, at $-68.1 \mathrm{~mm}$. The separation ratio, in terms of vertical displacement, ranged between 11.1 and $34.0 \%$.

4.1.2. Displacement of Block for $400 \mathrm{~mm}$ Reinforcement Spacing. Figure 7 and Table 7 show the vertical and horizontal displacement with respect to the height of the reinforced retaining wall block, for $400 \mathrm{~mm}$ reinforcement spacing.

The separation ratio, contrasting the original block size with the maximum displacement of the block, in terms of horizontal displacement, ranged between 4.5 and $12.9 \%$. The final horizontal displacement was maximum at $0.8 \mathrm{H}$, at $51.8 \mathrm{~mm}$.
The final vertical displacement was again negative throughout and increased in value with the height of the reinforced retaining wall, as was the case for the $200 \mathrm{~mm}$ reinforcement spacing. The biggest final vertical displacement observed was $-69.1 \mathrm{~mm}$ at the top $(H)$ of the reinforced retaining wall. The separation ratio, contrasting the original block size with the maximum displacement of the block, in terms of vertical displacement, ranged between 15.0 and 43.1\%. As shown in Figure 7(a), it was possible to observe a restoration to the original state at the heights of $0.2 \mathrm{H}$ and $0.4 \mathrm{H}$, after an initial movement into the backfill of the reinforced retaining wall. However, when observing the upper part of the reinforced retaining wall after the collision, it was found that the increase in block displacement had not absorbed the impulsive load of the vehicle due to a malfunction of the backfill and reinforcement. 
TABLE 7: Separation ratio for $400 \mathrm{~mm}$ reinforcement spacing.

\begin{tabular}{|c|c|c|c|c|c|c|}
\hline \multirow[b]{2}{*}{ Height } & \multicolumn{3}{|c|}{ Horizontal displacement (mm) } & \multicolumn{3}{|c|}{ Vertical displacement (mm) } \\
\hline & $\begin{array}{c}\text { Maximum } \\
\text { horizontal } \\
\text { displacement }\end{array}$ & $\begin{array}{l}\text { Separation } \\
\text { ratio } \\
(\%) \\
\end{array}$ & $\begin{array}{c}\text { Final } \\
\text { horizontal } \\
\text { displacement }\end{array}$ & $\begin{array}{c}\text { Maximum } \\
\text { vertical } \\
\text { displacement }\end{array}$ & $\begin{array}{c}\text { Separation } \\
\text { ratio } \\
(\%)\end{array}$ & $\begin{array}{l}\text { Final vertical } \\
\text { displacement }\end{array}$ \\
\hline $0.2 \mathrm{H}$ & 18.0 & 4.5 & 18.0 & -16.1 & 15.0 & -16.1 \\
\hline $0.4 H$ & 8.7 & 2.2 & 2.7 & -45.3 & 43.1 & -45.3 \\
\hline $0.6 H$ & 36.2 & 9.1 & 36.2 & -65.3 & 32.7 & -65.3 \\
\hline $0.8 H$ & 51.8 & 12.9 & 51.8 & -67.6 & 33.8 & -67.6 \\
\hline$H$ & -37.4 & 9.4 & 26.5 & -69.1 & 34.6 & -69.1 \\
\hline
\end{tabular}

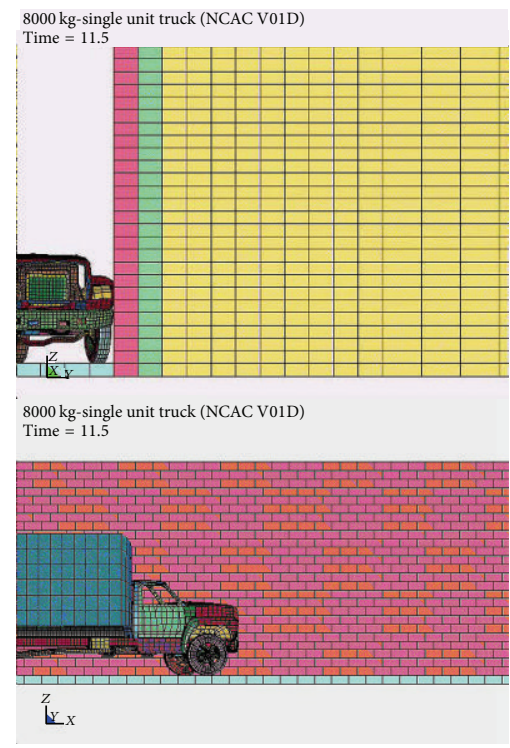

(a) $11.5 \mathrm{msec}$

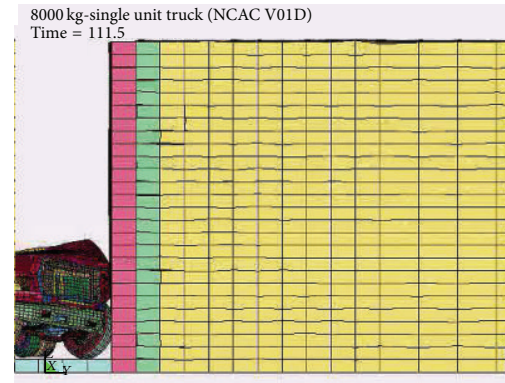

$8000 \mathrm{~kg}$-single unit truck (NCAC V01D)
Time $=111.5$

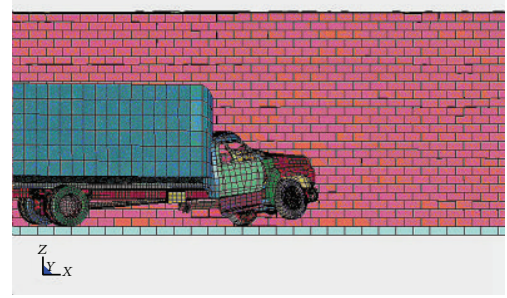

(b) $111.5 \mathrm{msec}$

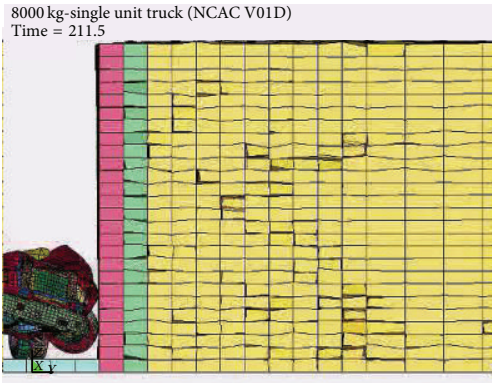

$8000 \mathrm{~kg}$-single unit truck (NCAC V01D)

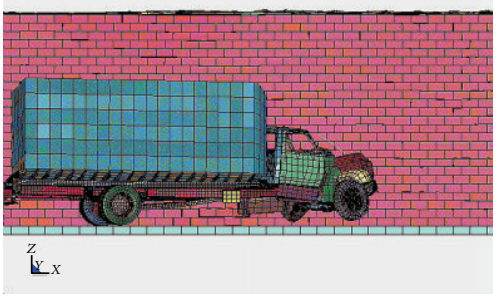

(c) $211.5 \mathrm{msec}$

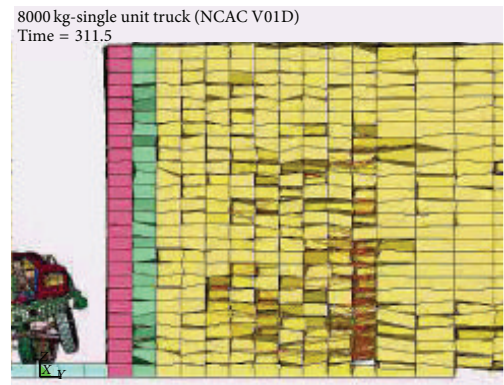

$8000 \mathrm{~kg}$-single unit truck (NCAC V01D)
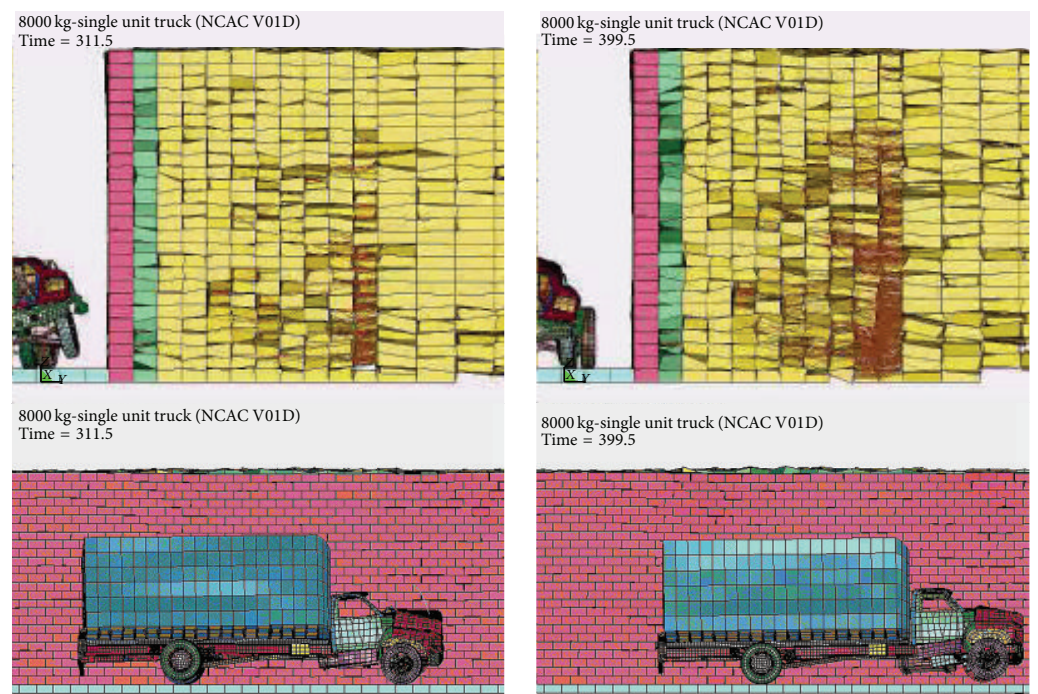

$\mathrm{Z}_{\mathrm{X}}$

$8000 \mathrm{~kg}$-single unit truck (NCAC V01D)
Time $=399.5$

Time $=399$

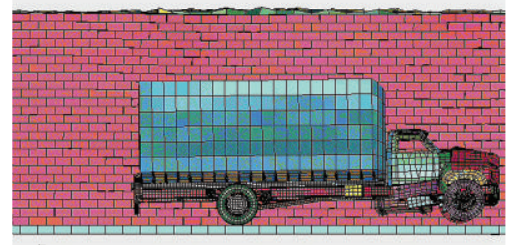

$\mathrm{L}_{\mathrm{x}}$

(d) $311.5 \mathrm{msec}$

(e) $399.5 \mathrm{msec}$

FIGURE 5: Behavior of reinforced retaining wall during vehicle collision. 


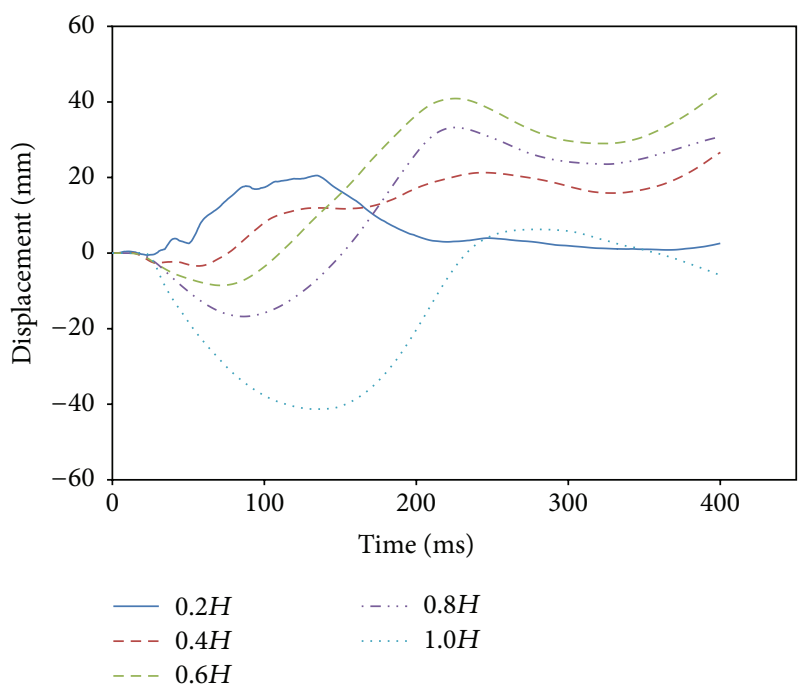

(a) Horizontal displacement of block with respect to elapsed time

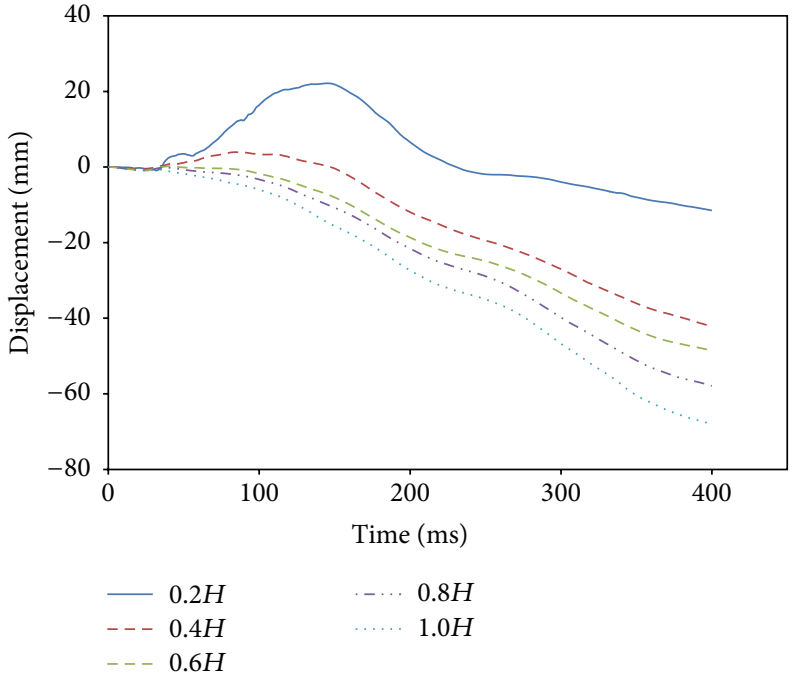

(b) Vertical displacement of block with respect to elapsed time

FIGURE 6: Block displacement for $200 \mathrm{~mm}$ reinforcement spacing.

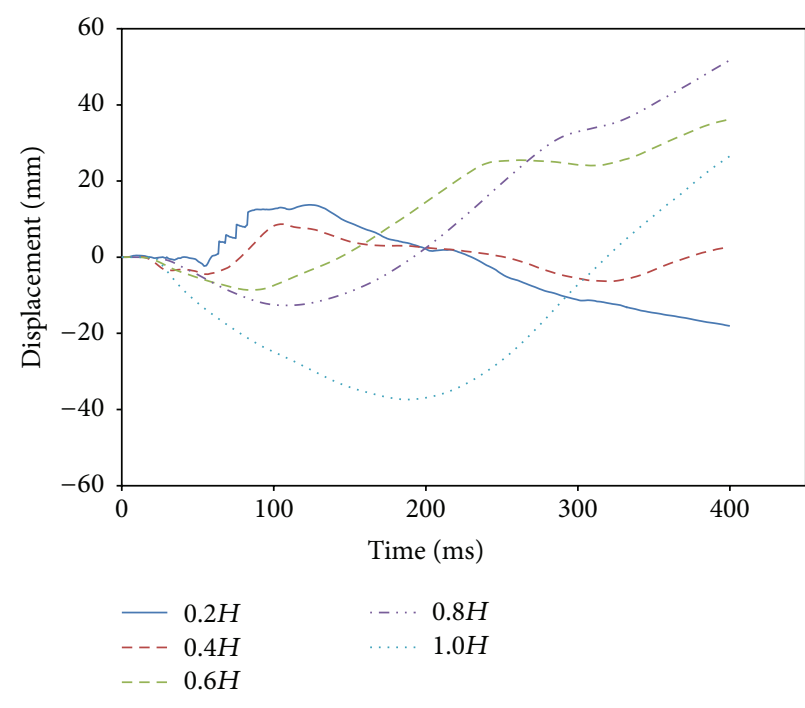

(a) Horizontal displacement of block with respect to elapsed time

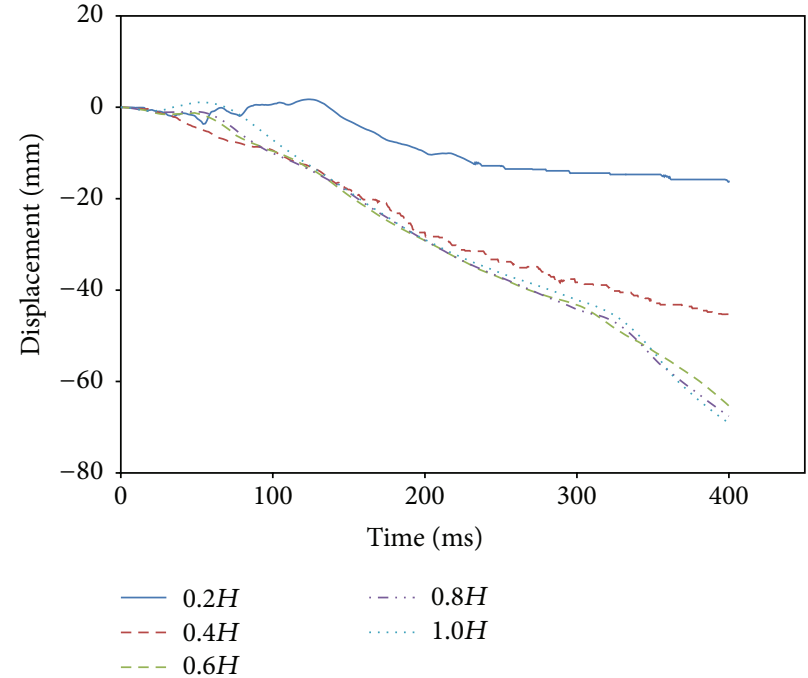

(b) Vertical displacement of block with respect to elapsed time

FIGURE 7: Block displacement for $400 \mathrm{~mm}$ reinforcement spacing.

4.1.3. Displacement of Block for $600 \mathrm{~mm}$ Reinforcement Spacing. Figure 8 and Table 8 show the vertical and horizontal displacement as a function of the height of the reinforced retaining wall block, for $600 \mathrm{~mm}$ reinforcement spacing.

As shown in Table 8, all the final horizontal displacements were found to be negative, with the largest final horizontal displacement found at the top of the reinforced retaining wall, with a value of $-107.1 \mathrm{~mm}$, and with the lowest final horizontal displacement at a height of $0.6 \mathrm{H}$ with a value of $-1.9 \mathrm{~mm}$. The separation ratio, contrasting the original block size with the maximum displacement of the block, in terms of horizontal displacement, ranged between 6.8 and $29.2 \%$. The final vertical displacements were all found to be negative values, and they increased in magnitude with increasing height of the reinforced retaining wall. The largest final vertical displacement, $-75.6 \mathrm{~mm}$, occurred at the top $(H)$ of the reinforced retaining wall, and the separation ratio, contrasting the original block size with the maximum displacement of the block, in terms of vertical displacement, ranged between 5.2 and $18.9 \%$. In Figure $8(a)$, the movement of the reinforced retaining wall block at $0.2 \mathrm{H}$ was found to be dangerous because the reinforced retaining wall at $0.2 \mathrm{H}$ was first moved in the direction of the backfill by the initial impact of the vehicle and then it moved again in the direction of the collided vehicle. This movement of the reinforced retaining wall at $0.2 \mathrm{H}$ makes the overturning of the structure possible. Furthermore, at this reinforcement spacing, a weaker resistance of the reinforcement was observed because the displacement 
TABLE 8: Block displacement for $600 \mathrm{~mm}$ reinforcement spacing.

\begin{tabular}{|c|c|c|c|c|c|c|}
\hline \multirow[b]{2}{*}{ Height } & \multicolumn{3}{|c|}{ Horizontal displacement (mm) } & \multicolumn{3}{|c|}{ Vertical displacement (mm) } \\
\hline & $\begin{array}{c}\text { Maximum } \\
\text { horizontal } \\
\text { displacement }\end{array}$ & $\begin{array}{c}\text { Separation ratio } \\
(\%)\end{array}$ & $\begin{array}{c}\text { Final horizontal } \\
\text { displacement }\end{array}$ & $\begin{array}{c}\text { Maximum } \\
\text { vertical } \\
\text { displacement }\end{array}$ & $\begin{array}{c}\text { Separation ratio } \\
(\%)\end{array}$ & $\begin{array}{l}\text { Final vertical } \\
\text { displacement }\end{array}$ \\
\hline $0.2 H$ & -27.0 & 6.8 & -27.0 & -20.9 & 5.2 & -20.8 \\
\hline $0.4 H$ & -39.5 & 9.9 & -39.5 & -49.8 & 12.4 & -49.8 \\
\hline $0.6 H$ & -11.6 & 2.9 & -1.9 & -58.2 & 14.6 & -58.2 \\
\hline $0.8 H$ & -33.6 & 8.4 & -14.1 & -64.9 & 16.2 & -64.9 \\
\hline$H$ & -116.7 & 29.2 & -107.1 & -75.6 & 18.9 & -75.6 \\
\hline
\end{tabular}

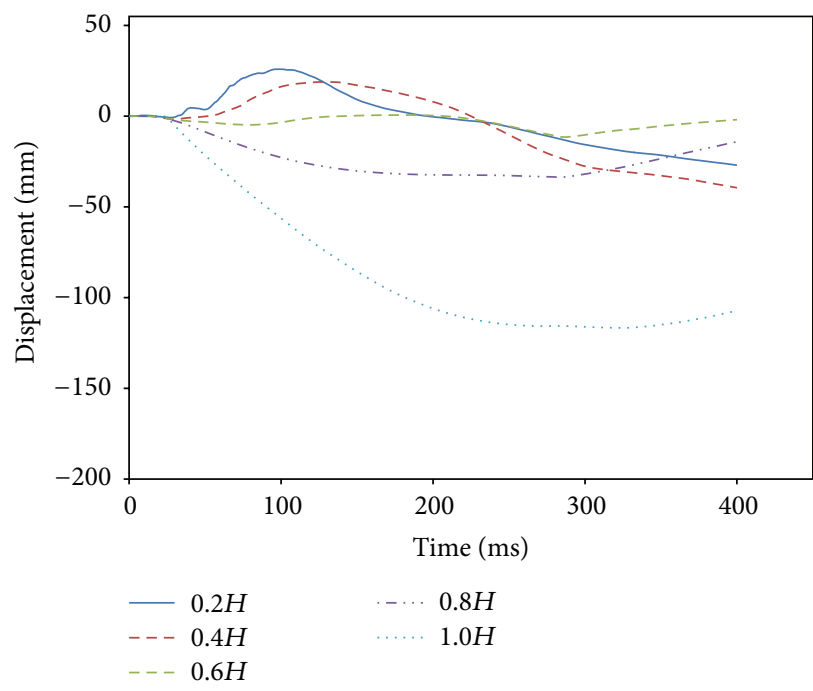

(a) Horizontal displacement of block with respect to the time elapsed

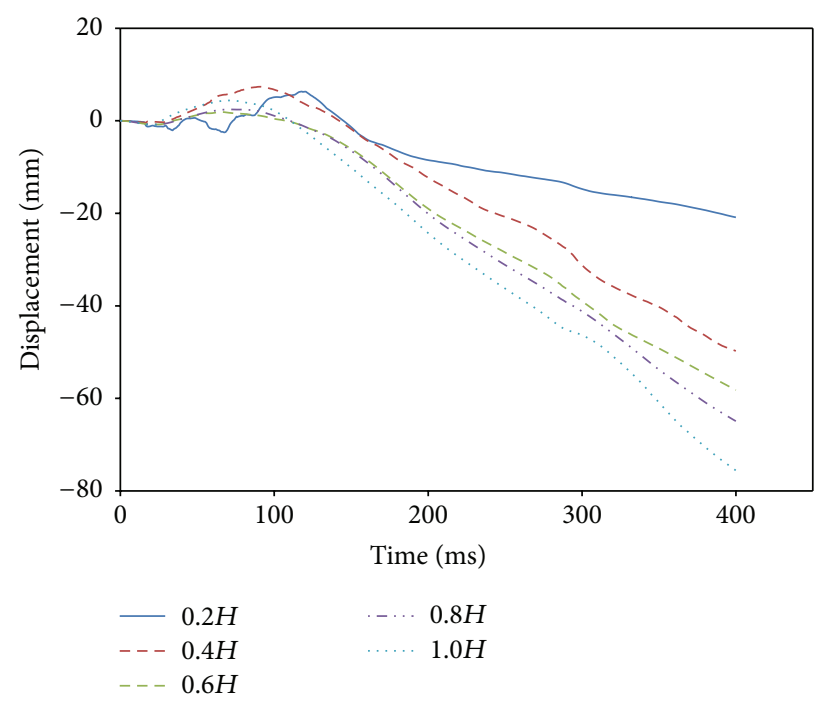

(b) Vertical displacement of block with respect to the time elapsed

FIGURE 8: Block displacement for $600 \mathrm{~mm}$ reinforcement spacing.

of the reinforced retaining wall did not recover after the displacement of the reinforced retaining wall increased.

\subsubsection{Comparison with Reinforced Retaining Wall Displace-} ments for Different Reinforcement Spacing. Figure 9 shows the absolute value of both the final horizontal and vertical displacements at $0.2 \mathrm{H}$ of the reinforced retaining wall for different reinforcement spacings. The final horizontal and vertical displacement increased with an increase in reinforcement spacing.

4.1.5. Effect of Reinforcement at the Top (H) of Reinforced Retaining Wall. As can be deduced from Figure 4, the highest point up to which reinforcement is located is $600 \mathrm{~mm}$ from the top of the reinforced retaining wall, for $600 \mathrm{~mm}$ reinforcement spacing. Similarly, it is $200 \mathrm{~mm}$ from the top of the reinforced retaining wall for $200 \mathrm{~mm}$ reinforcement spacing and $400 \mathrm{~mm}$ from the top of the reinforced retaining wall for $400 \mathrm{~mm}$ reinforcement spacing. As can be seen in Figure 10, the block at the top $(H)$ of the reinforced retaining wall considering the 200 and $400 \mathrm{~mm}$ reinforcement spacing more or less returned to the initial position. However, the block at the top $(H)$ of the reinforced retaining wall with
$600 \mathrm{~mm}$ reinforcement spacing did not recover its original position. This was because the reinforcement was located far from the top of the reinforced retaining wall. Based on this result, it can be deduced that the reinforcement spacing should be within $400 \mathrm{~mm}$ to ensure that reinforcement occurs up to the top of the reinforced retaining wall.

4.2. Behavior of Backfill for Different Reinforcement Spacing. A reinforced retaining wall serves as a normal retaining wall and is used for bridge abutment (the subbase course of roads) and as a structure surrounding a foundation. The backfill of the wall is a crucial factor in the success of all these functions and therefore requires further consideration because of its effect upon the safety of the structure and because of the irregularity of vehicle running.

Figure 11 shows the variation in the vertical displacement at the top of the backfill with different reinforcement spacing. The analyzed points along the length of the reinforced retaining wall which is $L$ were $0.1 L, 0.3 L, 0.5 L$, and $0.8 L$, where $0.5 \mathrm{~L}$ is the total length of the reinforcement. For all the reinforcement spacing considered $(200,400$, and $600 \mathrm{~mm})$, the $0.1 \mathrm{~L}$ point was closest to the collision surface of the vehicle, and it was found that the vertical displacement at this point 


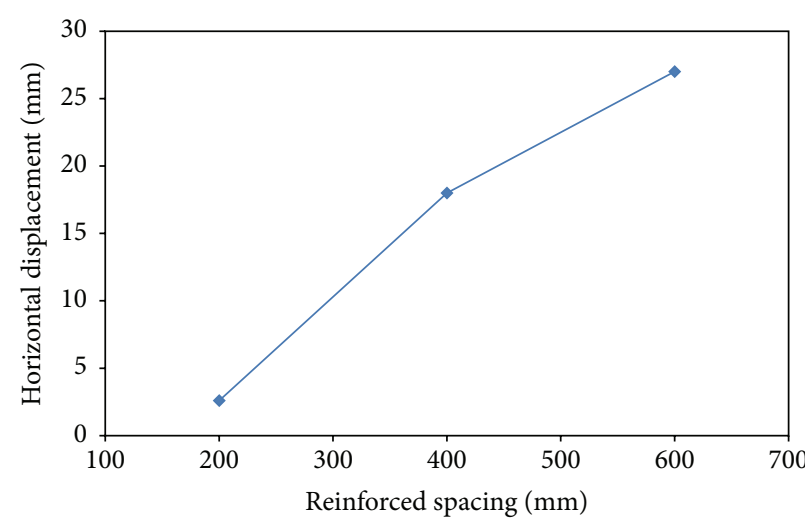

(a) Final horizontal displacement for different reinforcement spacing

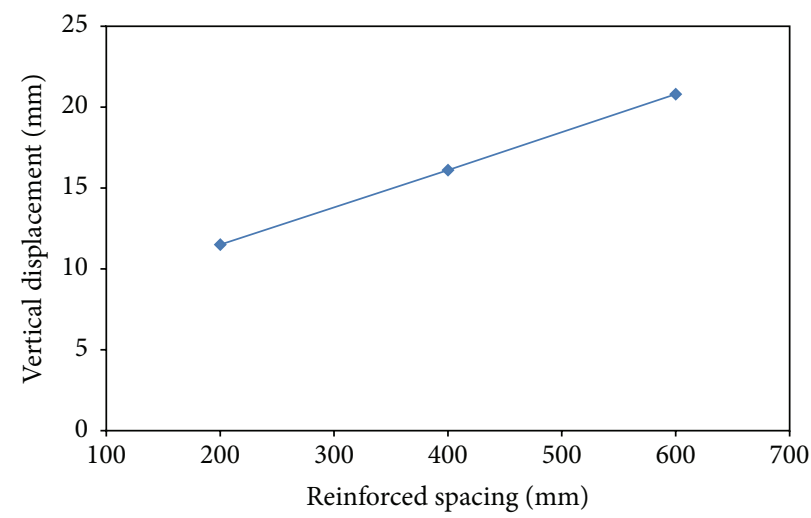

(b) Final vertical displacement for different reinforcement spacing

FIGURE 9: Final block displacement as a function of reinforcement spacing.

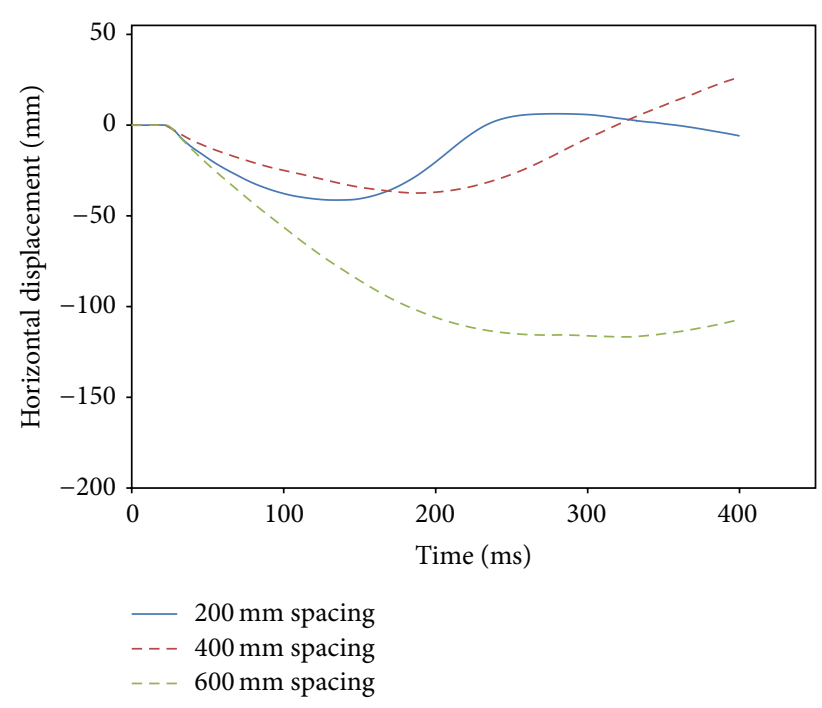

Figure 10: Block displacement at the top $(H)$ of reinforced retaining wall for reinforcement spacing.

had an invariably positive value, with no large variations for different spacing. The largest vertical displacement was observed at $0.5 \mathrm{~L}$, and the vertical displacements were -61.7 , -75.5 , and $-82.0 \mathrm{~mm}$ for 200,400 , and $600 \mathrm{~mm}$ reinforcement spacing, respectively. Additionally, the settlement also appeared at the points that were not reinforced.

\section{Conclusion}

In this study, the horizontal and vertical displacements of a reinforced retaining wall's front plate, affected by vehicle collision, were examined as functions of reinforcement spacing. The vertical displacement of backfill was also analyzed.

(1) Final horizontal and vertical displacements increased with increase in reinforcement spacing at $0.2 \mathrm{H}$ of the reinforced retaining wall height, a point that is close to the collision contact surface. This means that dense reinforcement spacing allows the reinforced

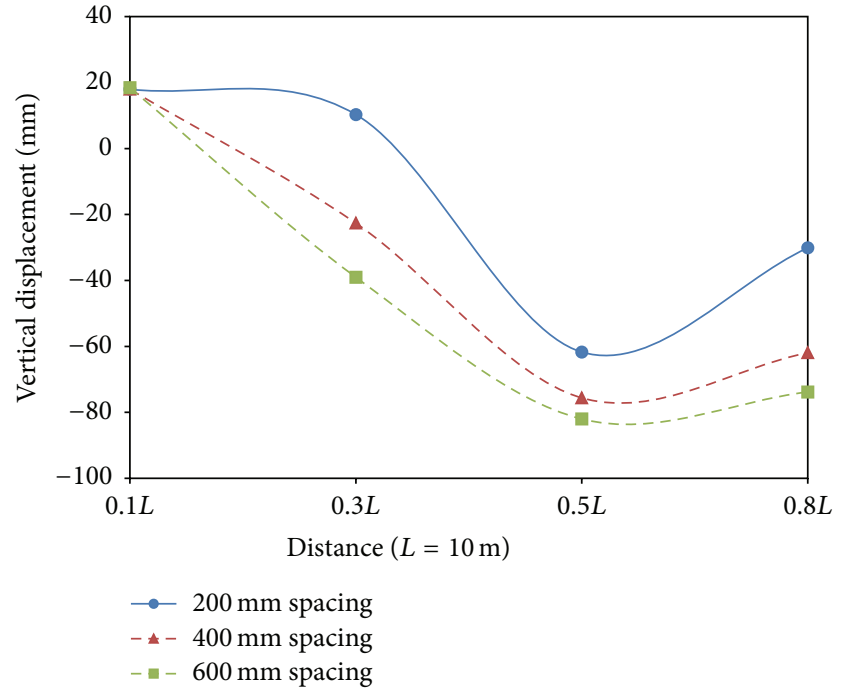

FIGURE 11: Final vertical displacements along the length of reinforcement for each reinforcement spacing $(200,400$, and $600 \mathrm{~mm})$.

retaining wall to strongly resist external collision load. A decrease in both horizontal and vertical displacement was observed when the interval between reinforcement was decreased. It is possible to conclude that reinforcement spacing is an important resistance factor against external collision load.

(2) When considering $200 \mathrm{~mm}$ and $400 \mathrm{~mm}$ of reinforcement spacing, the horizontal and vertical displacements were restored in time, after the reinforced retaining wall was impacted by vehicle collision. This means that these reinforcement spacing values (such as $200 \mathrm{~mm}$ and $400 \mathrm{~mm}$ ) can withstand an external collision load. However, there was no restoration for the $600 \mathrm{~mm}$ reinforcement spacing. This was deduced to be because reinforcement did not reach up to the top of the reinforced retaining wall. Therefore, it is possible to conclude that the reinforcement spacing has to be considered alongside the total height of 
the reinforced retaining wall, in order to strengthen the safety of the reinforced retaining wall.

(3) $-61.7,-75.5$, and $-82.0 \mathrm{~mm}$ displacements of the top of backfill were examined. It was possible to conclude from these observations that reinforcement affects backfill in its resistance against external collision load and that the nature of the reinforcement is a necessary factor to be considered, when reinforced retaining walls are designed.

\section{Conflict of Interests}

The authors declare that there is no conflict of interests regarding the publication of this paper.

\section{References}

[1] V. N. Ghionna, V. Fioravante, and M. Vicari, "Full scale test on a retaining wall non-uniform reinforcements," in Proceedings of the 7th International Conference on Geosynthetics (ICG '02), pp. 279-282, September 2002.

[2] D. Leshchinsky and C. Vulova, "Numerical investigation of the effects of geosynthetic spacing on failure mechanisms in MSE block walls," Geosynthetics International, vol. 8, no. 4, pp. 343365, 2001.

[3] H. Liu and M.-S. Won, "Long-term reinforcement load of geosynthetic-reinforced soil retaining walls," Journal of Geotechnical and Geoenvironmental Engineering, vol. 135, no. 7, pp. 875889, 2009.

[4] M. I. M. Pinto and T. W. Cousens, "Modelling a geotextilereinforced, brick-faced soil retaining wall," Geosynthetics International, vol. 6, no. 5, pp. 417-447, 1999.

[5] A. W. Stuedlein, T. M. Allen, R. D. Holtz, and B. R. Christopher, "Assessment of reinforcement strains in very tall mechanically stabilized earth walls," Journal of Geotechnical and Geoenvironmental Engineering, vol. 138, no. 3, pp. 345-356, 2012.

[6] S. B. A. Mohamed, K.-H. Yang, and W.-Y. Hung, "Finite element analyses of two-tier geosynthetic-reinforced soil walls: comparison involving centrifuge tests and limit equilibrium results," Computers and Geotechnics, vol. 61, pp. 67-84, 2014.

[7] K. S. Wong, B. B. Broms, and B. Chandrasekaran, "Failure modes at model tests of a geotextile reinforced wall," Geotextiles and Geomembranes, vol. 13, no. 6-7, pp. 475-493, 1994.

[8] C. Yoo and H.-Y. Jung, "Case history of geosynthetic reinforced segmental retaining wall failure," Journal of Geotechnical and Geoenvironmental Engineering, vol. 132, no. 12, pp. 1538-1548, 2006.

[9] M. Borovinšek, M. Vesenjak, M. Ulbin, and Z. Ren, "Simulation of crash tests for high containment levels of road safety barriers," Engineering Failure Analysis, vol. 14, no. 8, pp. 1711-1718, 2007.

[10] C. B. Ju, "A study on the embedded depth of guardrail posts," Study of Highway and Transportation Technology Institute in Korea, 2003.

[11] Y. Itoh, C. Liu, and R. Kusama, "Dynamic simulation of collisions of heavy high-speed trucks with concrete barriers," Chaos, Solitons and Fractals, vol. 34, no. 4, pp. 1239-1244, 2007.

[12] J. Kim, S. Lee, and H. Choi, "Progressive collapse resisting capacity of moment frames with viscous dampers," The Structural Design of Tall and Special Buildings, vol. 22, no. 5, pp. 399414, 2013.
[13] S. K. Tay, B. Lim, and N. G. S. Herng, "Crash impact modelling of security bollard," in Proceedings of the 12th International LSDYNA Users Conference 13, pp. 1-10, June 2012.

[14] W. Wu and R. Thomson, "A study of the interaction between a guardrail post and soil during quasi-static and dynamic loading," International Journal of Impact Engineering, vol. 34, no. 5, pp. 883-898, 2007.

[15] K. Ahn, Y. Heo, K. Hong, and M. Ahn, "Behavior of reinforced earth retaining wall with vehicle collision," Journal of the Korean Geoenvironmental Society, vol. 11, no. 6, pp. 39-46, 2010.

[16] Ministry of Land, Transport, and Maritime Affairs in Korea, Business Guide for Vehicle Crash Test of Safety Facility of Vehicle Protection, Ministry of Land, Transport and Maritime Affairs in Korea, 2008.

[17] Guidelines for Installation and Administration of Load Safety Facility, Ministry of Land, Transport and Maritime Affairs in Korea, 2014. 

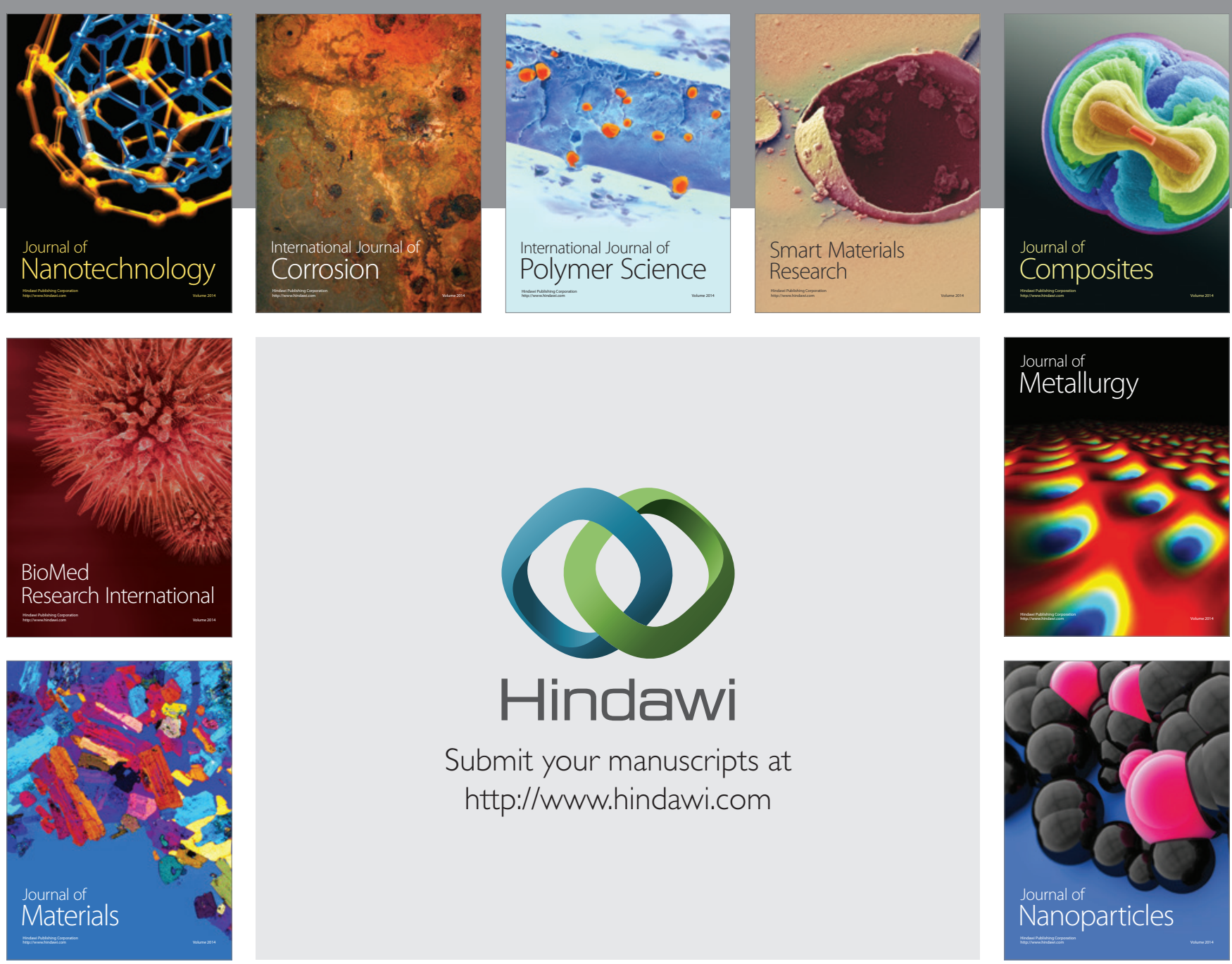

Submit your manuscripts at http://www.hindawi.com
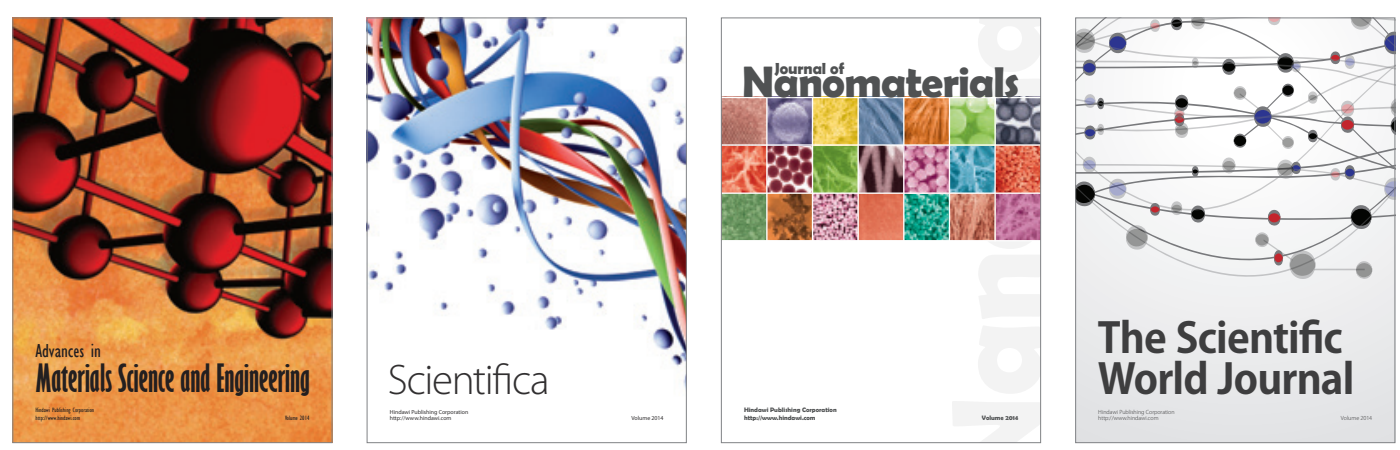

\section{The Scientific World Journal}
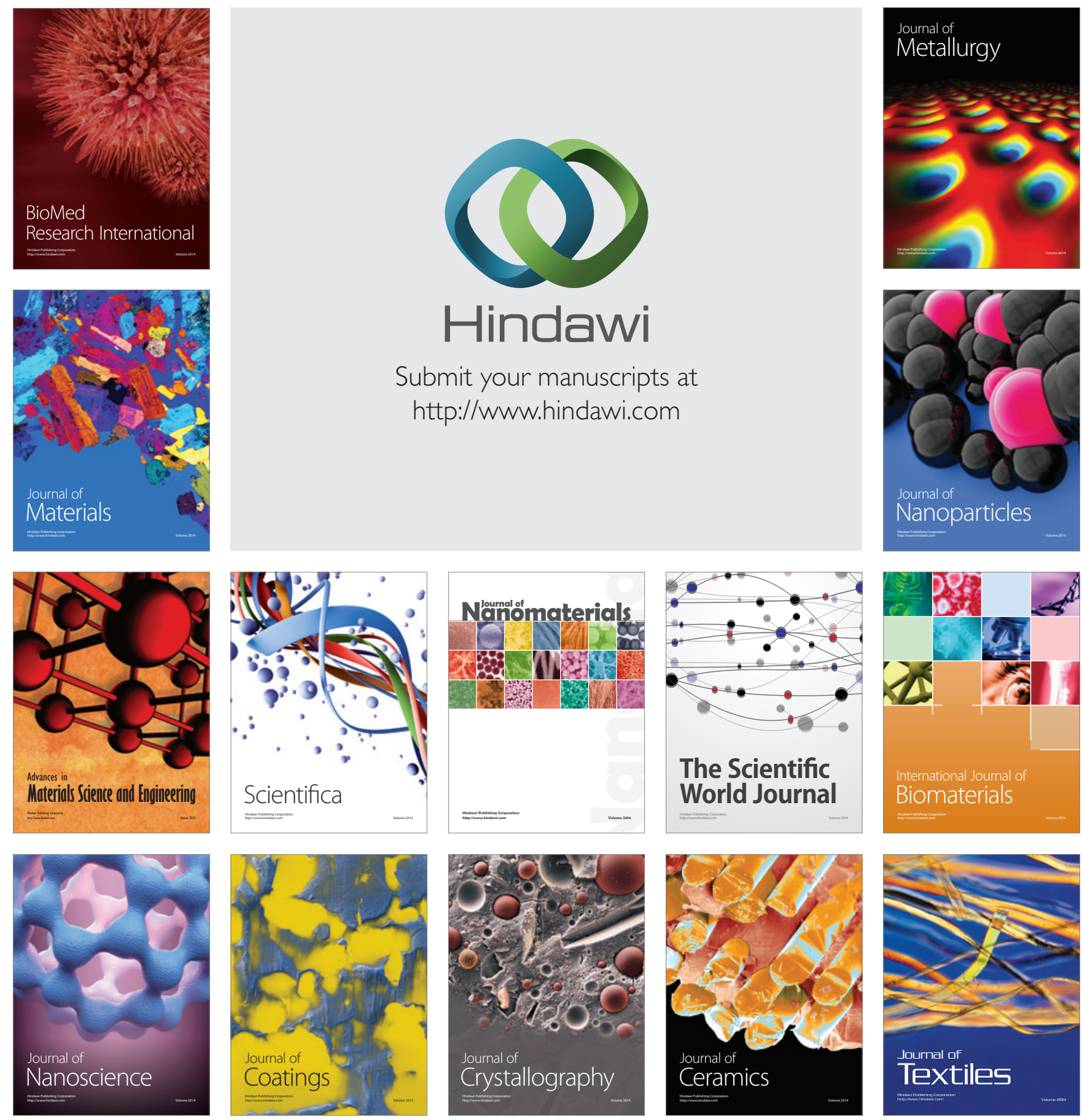